\title{
An Estimated DSGE Model for the United Kingdom
}

\author{
Riccardo DiCecio and Edward Nelson
}

\begin{abstract}
The authors estimate the dynamic stochastic general equilibrium model of Christiano, Eichenbaum, and Evans (2005) on U.K. data. Their estimates suggest that price stickiness is a more important source of nominal rigidity in the United Kingdom than wage stickiness. Their estimates of parameters governing investment behavior are only well behaved when post-1979 observations are included, which reflects government policies until the late 1970s that obstructed the influence of market forces on investment. (JEL E31, E32, E52)
\end{abstract}

Federal Reserve Bank of St. Louis Review, July/August 2007, 89(4), pp. 215-31.

$\mathrm{n}$ this paper we estimate a dynamic stochastic general equilibrium (DSGE) model with nominal rigidities for the U.K. economy. The model we estimate is due to Christiano, Eichenbaum, and Evans (2005; CEE) and has become a benchmark, matching important aspects of the U.S. data while also being derived from optimizing behavior.

Interest in DSGE modeling of the United Kingdom has been heightened in recent years with the introduction of the Bank of England quarterly model (BEQM) into the U.K. monetary policy process. This model is based to a considerable degree on explicit optimizing foundations; see Harrison et al. (2005) for the model and Pagan (2005) for a discussion. BEQM is, however, dissimilar in important respects from the CEE model of the United States and the variant of the CEE model that Smets and Wouters (2003) estimate for the euro area. These dissimilarities make it difficult to use BEQM to compare the structure of the U.K. economy with that of other economies. For example, the estimation procedure for BEQM is different from that used by CEE and by Smets and Wouters; portions of the BEQM model are estimated over a considerably shorter sample than CEE consider for the United States, and there are deviations from explicit optimization in the dynamics of the BEQM model.

All in all, it is probably fair to say that there has been considerably less work done for the United Kingdom in terms of DSGE modeling with systems estimation than there has been for other economies. But U.K. data may contain a type of information that is ideal for estimation of a DSGE model-specifically, information on private sector responses to policy actions. As the present governor of the Bank of England, Mervyn King, observed some 30 years ago,
Maintenance of the existing order and existing rates produces no information, whereas more information can be obtained by making changes. In this respect the U.S....is at a dis- advantage by comparison with the U.K. A good illustration of this is afforded by the excite- ment generated amongst American economists in the 1960 s by the investment tax credit and the attempts to assess its effects. A British economist would have shrugged this off as a

Riccardo DiCecio is an economist at the Federal Reserve Bank of St. Louis, and Edward Nelson is an assistant vice president at the Federal Reserve Bank of St. Louis and a research affiliate at the Centre for Economic Policy Research. The authors thank Adrian Pagan and participants at the policy conference and in seminars at the Federal Reserve Bank of Atlanta for comments on an earlier draft and Nick Davey, Jennifer Greenslade, and Kenny Turnbull for helpful information. Justin Hauke provided research assistance.

(C) 2007, The Federal Reserve Bank of St. Louis. Articles may be reprinted, reproduced, published, distributed, displayed, and transmitted in their entirety if copyright notice, author name(s), and full citation are included. Abstracts, synopses, and other derivative works may be made only with prior written permission of the Federal Reserve Bank of St. Louis. 


\section{Table 1}

\section{Parameters in the Model}

\begin{tabular}{|c|c|c|c|}
\hline Parameter & Description & Parameter & Description \\
\hline$\beta$ & Discount factor & $\xi_{p}$ & Degree of price stickiness \\
\hline$\alpha$ & $\begin{array}{l}\text { Production elasticity with respect } \\
\text { to capital }\end{array}$ & $\xi_{w}$ & Degree of wage stickiness \\
\hline$\delta$ & Depreciation rate & $1 / \kappa$ & Elasticity of investment to $\hat{p}_{K^{\prime}}$ \\
\hline$\mu$ & Steady-state money-growth rate & $1 / \sigma_{a}$ & Elasticity of utilization to $\hat{r}^{k}$ \\
\hline$\psi_{l}$ & Relative weight of leisure in utility & $\rho$ & Interest rate smoothing parameter \\
\hline$\psi_{q}$ & $\begin{array}{l}\text { Relative weight of real balances } \\
\text { in utility }\end{array}$ & $r_{\pi}$ & Interest rate response to inflation \\
\hline$\lambda_{w}$ & Wage markup & $r_{y}$ & Interest rate response to output \\
\hline $1 / \sigma_{q}$ & $\begin{array}{l}\text { Interest semi-elasticity of money } \\
\text { demand }\end{array}$ & $r_{\Delta \pi}$ & $\begin{array}{l}\text { Interest rate response to change } \\
\text { in inflation }\end{array}$ \\
\hline$b$ & Habits parameter & $r_{\Delta y}$ & $\begin{array}{l}\text { Interest rate response to change in } \\
\text { output }\end{array}$ \\
\hline$\lambda_{f}$ & Price markup & $\sigma_{\varepsilon}$ & $\begin{array}{l}\text { Standard deviation of monetary policy } \\
\text { shock }\end{array}$ \\
\hline
\end{tabular}

mere trifle compared to the changes he had witnessed over the years. (King, 1977, p. 6)

This observation, though made with reference to the changes wrought in U.K. fiscal policy up to the 1960s, applies tenfold to monetary policy experience in the period since the 1960s. Over that period, the United Kingdom has undergone great variation in inflation, interest rates, and monetary regimes. ${ }^{1}$ It is true that for estimation this is a mixed blessing because large regime changes make it problematic to estimate a structural model over a long sample. But Christiano, Eichenbaum, and Evans (1999) and Sims and Zha (2006) argue for the United States that constantparameter policy reaction functions may be reasonable approximations even over long samples, a view also implicit in CEE's (2005) choice of a 1965-95 estimation period. In modeling the United Kingdom using a DSGE model, we make a compromise between these positions by treating the

1 Various advantages of the U.K. data for testing macroeconomic hypotheses have been stressed by Ravn (1997) (evaluating a real business cycle model against the behavior of U.K. real aggregates), Nelson and Nikolov (2004) (using a small New Keynesian model to evaluate different U.K. policy regimes), and Benati (2004) (assessing the behavior of U.K. data moments over the postwar period). period since 1979 as a single regime,,$^{2}$ but also by presenting results for pre-1979 and a long sample covering 1962-2005. ${ }^{3}$

We present in the following sections our model, estimates for our main sample, and results for the longer sample, with a discussion of other regime-change issues.

\section{MODEL}

The model is the same as that in CEE (2005), by now standard in the DSGE literature. The model incorporates both nominal frictions (sticky prices and wages) and dynamics in preferences and production (habit formation in consumption, investment adjustment costs, and variable capital utilization). The pattern of timing in agents' decisions is consistent with the VAR identification

\footnotetext{
2 Some work for the United Kingdom (e.g., Castelnuovo and Surico, 2006) focuses on 1992 as the start of the present policy regime. But our use of a baseline sample period that starts in the late 1970s matches the choices implied by some of the BEQM-equation estimation periods (see, e.g., Harrison et al., 2005, pp. 115-20).

3 The long-sample estimates are the U.K. analogue to the Del Negro et al. (2005) treatment of the U.S. sample 1954-2004 as a single regime (including an unchanged inflation target).
} 
Table 2

\section{Variable Definitions}

\begin{tabular}{llll} 
Variable & \multicolumn{1}{c}{ Description } & Variable & \multicolumn{1}{c}{ Description } \\
\hline$\hat{m}$ & Real money supply & $\hat{\pi}$ & Inflation \\
$\hat{q}$ & Households' demand for money & $\hat{w}$ & Real wage \\
$\hat{k}$ & Capital services & $\hat{r}^{k}$ & Rental rate on capital \\
$\hat{\hat{k}}$ & Physical capital & $\hat{\mu}$ & Growth rate of nominal money stock \\
$\hat{l}$ & Labor & $\hat{p}_{K^{\prime}}$ & Price of capital \\
$\hat{c}$ & Consumption & $\hat{U}_{C}$ & Marginal utility of consumption \\
$\hat{i}$ & Investment & $\hat{R}$ & Nominal interest rate \\
$\hat{y}$ & Output & & \\
\hline
\end{tabular}

restriction that we use in the next section. In our outline here of the linearized version of the model, all variables are expressed in log-deviations from their steady-state values. For convenience, model parameters and variables are summarized in Tables 1 and 2, respectively.

Prices are governed by Calvo (1983) contracts, augmented by indexation to the previous period's inflation for those firms not allowed to reoptimize their pricing decision. The implied inflation dynamics are given by the following Phillips curve:

(1) $E_{t-1}\left(\begin{array}{l}\frac{\beta \xi_{p}}{\left(1-\xi_{p}\right)\left(1-\beta \xi_{p}\right)} \hat{\pi}_{t+1}-\frac{\xi_{p}(1+\beta)}{\left(1-\xi_{p}\right)\left(1-\beta \xi_{p}\right)} \hat{\pi}_{t} \\ +\frac{\xi_{p}}{\left(1-\xi_{p}\right)\left(1-\beta \xi_{p}\right)} \hat{\pi}_{t-1} \\ +\left[\alpha \hat{r}_{t}^{k}+(1-\alpha)\left(\hat{R}_{t}+\hat{w}_{t}\right)\right]\end{array}\right)=0$.

Here, hats on variables indicate the log-deviations from steady-state values. For the nominal interest rate and inflation terms that appear in the model, the hatted variables are effectively the demeaned net inflation and interest rates, because the log-deviations are computed using gross rates.

Nominal wages are staggered along similar lines to prices, ${ }^{4}$ with a clause for indexation to

4 See Erceg, Henderson, and Levin (2000) for the development of this form of staggered wage contracts. the preceding period's price inflation. This produces the nominal wage equation:

(2) $E_{t-1}\left(\begin{array}{l}\varpi_{1} \hat{w}_{t+1}+\varpi_{2} \hat{w}_{t}+\varpi_{3} \hat{w}_{t-1}+\varpi_{4} \hat{\pi}_{t+1} \\ +\varpi_{5} \hat{\pi}_{t}+\varpi_{6} \hat{\pi}_{t-1}+\hat{U}_{C, t}-\hat{l}_{t}\end{array}\right)=0$,

where

$$
\begin{aligned}
& \varpi_{1}=\frac{-\beta \xi_{w}}{\left(1-\beta \xi_{w}\right)\left(1-\xi_{w}\right)}\left(1+\frac{\lambda_{w}}{\lambda_{w}-1}\right) \\
& \varpi_{2}=\frac{1+\beta \xi_{w}^{2}}{\left(1-\beta \xi_{w}\right)\left(1-\xi_{w}\right)}\left(1+\frac{\lambda_{w}}{\lambda_{w}-1}\right)-\frac{\lambda_{w}}{\lambda_{w}-1}, \\
& \varpi_{3}=\frac{-\xi_{w}}{\left(1-\beta \xi_{w}\right)\left(1-\xi_{w}\right)}\left(1+\frac{\lambda_{w}}{\lambda_{w}-1}\right) \\
& \varpi_{4}=\varpi_{1}, \varpi_{6}=\varpi_{3}, \\
& \varpi_{5}=\frac{\xi_{w}(1+\beta)}{\left(1-\beta \xi_{w}\right)\left(1-\xi_{w}\right)}\left(1+\frac{\lambda_{w}}{\lambda_{w}-1}\right)
\end{aligned}
$$

Firms' optimality conditions imply that their total payments for capital services equal their total cost of hiring labor each period:

$$
\hat{r}_{t}^{k}+\hat{k}_{t}=\hat{w}_{t}+\hat{R}_{t}+\hat{l}_{t} .
$$

Underlying this condition is the assumption that firms finance their wage bill with funds borrowed one period earlier. Real unit labor costs are therefore (in log terms) equal to the sum of the real wage and the short-term nominal interest rate. 
The typical household's intertemporal Euler equation for consumption and first-order condition for capital purchases are, respectively,

$$
\hat{U}_{C, t}=E_{t}\left(\hat{R}_{t+1}-\hat{\pi}_{t+1}+\hat{U}_{C, t+1}\right)
$$

$$
E_{t-1}\left(\hat{p}_{K^{\prime}, t}+\hat{U}_{C, t}\right)
$$

(5)

$$
=E_{t-1}\left(\hat{U}_{C, t+1}+\frac{r^{k}}{r^{k}+1-\delta} \hat{r}_{t+1}^{k}+\frac{1-\delta}{r^{k}+1-\delta} \hat{p}_{K^{\prime}, t+1}\right) .
$$

Because of habit formation in preferences, the household marginal utility of consumption that appears in the above expressions is not a static function of consumption. Instead, it depends on the current, prior, and expected future levels of consumption:

$$
\begin{aligned}
& (1-b \beta)(1-b) E_{t-1} \hat{U}_{C, t}-b \beta E_{t-1} \hat{c}_{t+1} \\
& +\left(1+b^{2} \beta\right) E_{t-1} \hat{c}_{t}-b \hat{c}_{t-1}=0 .
\end{aligned}
$$

The economy's technology allows additional productive services to be generated, at a cost, from an unchanged stock of physical capital. The degree of capital utilization-that is, the difference between the physical capital stock (denoted by an overbar) and capital services-is chosen by households to equate marginal cost with marginal benefit:

$$
E_{t-1}\left(\hat{k}_{t}-\hat{\bar{k}}_{t}\right)=\frac{1}{\sigma_{a}} E_{t-1} \hat{r}_{t}^{k},
$$

where $1 / \sigma_{a}$ is the elasticity of the utilization function.

The equilibrium condition for household investment choices can be written as

(8) $E_{t-1} \hat{p}_{K^{\prime}, t}=\kappa E_{t-1}\left(\hat{\imath}_{t}-\hat{\imath}_{t-1}\right)-\beta \kappa E_{t-1}\left(\hat{\imath}_{t+1}-\hat{\imath}_{t}\right)$.

This condition indicates that the price firms pay for capital services is a function of two parameters that emerge from the behavior of households (who are the producers and suppliers of capital services): the households' discount factor, $\beta$, and the elasticity of their investment adjustment cost function, $1 / \kappa$.

The stock of physical capital obeys the law of motion:

$$
\hat{\bar{k}}_{t+1}=(1-\delta) \hat{\bar{k}}_{t}+\delta \hat{\imath}_{t},
$$

where $\delta$ denotes the depreciation rate. Though physical investment is subject to adjustment costs, equation (9) indicates that a unit of investment adds to the physical capital stock in a standard manner.

Households' money demand function is given by

$$
\hat{q}_{t}=-\frac{1}{\sigma_{q}}\left[\frac{R}{R-1} \hat{R}_{t}+\hat{U}_{C, t}\right],
$$

a condition that indicates the standard choice between holding money for the transaction services it provides ${ }^{5}$ or, instead, holding one-period securities for interest income.

The following identity relates growth of nominal money supply to inflation and changes in real money supply:

$$
\hat{\mu}_{t-1}=\hat{m}_{t}-\hat{m}_{t-1}+\hat{\pi}_{t} .
$$

The aggregate demand for money in the economy comes from two sources: demand by firms (to finance their wage bill) and by households as given by condition (10). In equilibrium, total money demand is equal to the aggregate money stock:

$$
q \hat{q}_{t}+w l\left(\hat{w}_{t}+\hat{l}_{t}\right)=\mu m\left(\hat{\mu}_{t}+\hat{m}_{t}\right) .
$$

The resource constraint and the aggregate production function can be written as

(13) $\left(\frac{1}{\beta}+\delta-1\right) \frac{K}{Y}\left(\hat{k}_{t}-\hat{\bar{k}}_{t}\right)+\frac{C}{Y} \hat{c}_{t}+\delta \frac{K}{Y} \hat{\imath}_{t}=\hat{y}_{t}$

$$
\hat{y}=\alpha \lambda_{f} \hat{k}_{t}+(1-\alpha) \lambda_{f} \hat{l}_{t} .
$$

Equation (13) indicates that resources this period can be consumed, invested, or used to generate additional capital utilization. Equation (14) indicates that the two inputs in production are labor and capital services.

Monetary policy follows a dynamic version of the Taylor rule:

\footnotetext{
5 Because of habit formation, prior and expected future transactions create a demand for real balances-i.e., money over and above the demand generated by current transactions.
} 


$$
\begin{aligned}
\hat{R}_{t} & =\rho \hat{R}_{t-1}+(1-\rho)\left[r_{\pi} \hat{\pi}_{t}+r_{y} \hat{y}_{t}\right] \\
& +r_{\Delta \pi}\left(\hat{\pi}_{t}-\hat{\pi}_{t-1}\right)+r_{\Delta y}\left(\hat{y}_{t}-\hat{y}_{t-1}\right)-\varepsilon_{t} .
\end{aligned}
$$

The short-term nominal interest rate is therefore a smoothed function of inflation, output, and changes in inflation and output. There is also a monetary policy shock, $\varepsilon_{t}$. This rule is similar to that in Smets and Wouters (2003) and Levin et al. (2005).

Other than our use of an interest rate rule, the model we use corresponds to the CEE benchmark. A limitation in our application to the U.K. data is that the CEE model describes a closed economy. But there are several reasons for using a closed-economy model when analyzing the United Kingdom; see Neiss and Nelson (2003) for a discussion. For the present paper, the main reasons why a closed economy of the DSGE model might be suitable for the United Kingdom are as follows: (i) Openness makes it difficult to model capital formation endogenously, whereas the presence of endogenous capital is a key feature of the CEE model. And (ii) the simplest openeconomy models give counterfactual weight to the exchange rate in consumer price inflation dynamics; once the exchange-rate channel is "tamed" by such approaches as assuming incomplete pass-through, imported intermediates, etc., the model's properties become more like those of a closed economy (see, e.g., Obstfeld, 2002).

\section{ESTIMATION}

To estimate the model, we first obtain data responses to a monetary policy shock from a vector autoregression (VAR) for the United Kingdom. Then, as in CEE, we match these impulse responses as closely as possible with the CEE model, using a minimum-distance estimation procedure. ${ }^{6}$ Our analysis here is limited to monetary policy shocks, but there is evidence for the United States that estimates of the CEE model are robust to incorporating technology shocks into the analysis (see DiCecio, 2005, and Altig et al., 2005).

6 This procedure was also used with a smaller VAR by Rotemberg and Woodford (1997).

\section{VAR Estimates}

We estimate our VAR on a U.K. dataset consisting of a subset of the variables studied in the U.S. case by CEE. Our VAR contains the logs of real gross domestic product (GDP), real consumption, ${ }^{7}$ real investment, and labor productivity, as well as the nominal Treasury bill rate and the quarterly (retail) inflation rate. ${ }^{8}$ As these choices imply, our focus is on the response of the policy rate, inflation, and aggregate demand to a monetary policy shock, as well as the split of aggregate demand among its components and the division of the output response between labor and other inputs.

The sample period is 1979:Q2-2005:Q4. The start date is the quarter corresponding to the period (May 1979) in which the Thatcher government first took office-and so an important monetary policy regime change. ${ }^{9}$ It also corresponds approximately to the date of some other significant changes in government policy that are important for the VAR responses, as we discuss in the next section.

Figure 1 plots the estimated VAR responses to a monetary policy shock and their bootstrapped confidence intervals, along with the match to each response made by our estimates of the CEE model; the model-based responses are the blue lines. Parameters fixed in estimation are given in Table 3.

\section{Parameter Estimates}

The parameter estimates resulting from this matching of impulse responses are given in Table 4. Standard errors for the parameter estimates appear in parentheses and are calculated by the asymptotic delta method. ${ }^{10}$

\footnotetext{
7 We have not split consumption between durables and nondurables. VAR impulse responses in Aoki, Proudman, and Vlieghe (2002, Chart 2), using a different VAR specification and sample period from ours, found similar response functions for the two types of consumption.

8 Our VAR does not include a time trend. Impulse responses look similar regardless of whether a linear trend is included in the VAR.

9 See, e.g., Goodhart (1989) for a perspective on this regime change.

${ }^{10}$ See Newey and McFadden (1994, p. 2145).
} 


\section{Figure 1}

\section{Estimated and Model Responses to a Monetary Policy Shock}
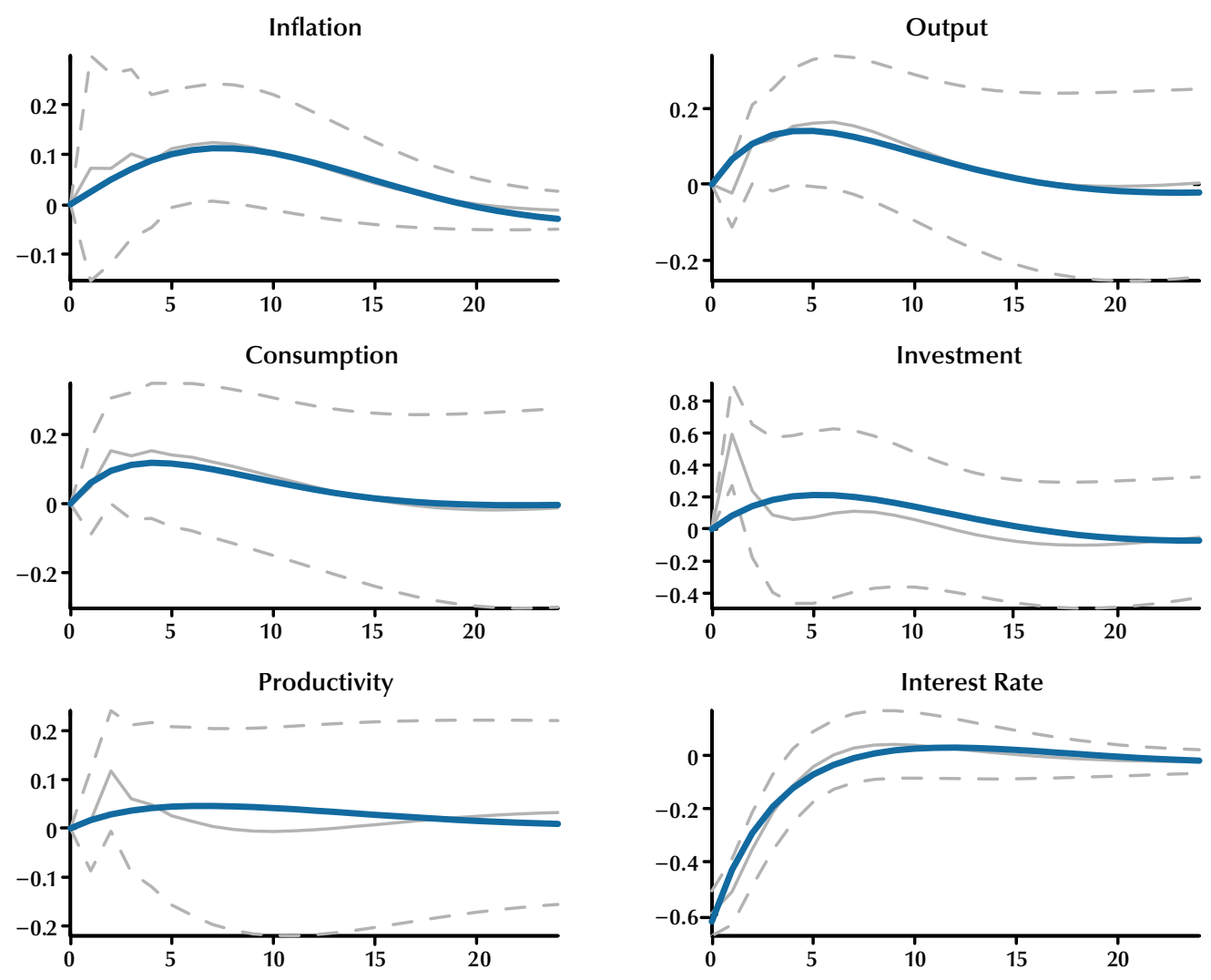

The parameter indexing habit formation in consumption is larger than that estimated by CEE and Altig et al. (2005) but is basically in line with Fuhrer (2000). So the degree of habit formation in the United Kingdom appears similar to U.S. estimates.

The markup estimate is, at somewhat above 2 , high by the standards of calibrated and estimated DSGE models. It is, however, roughly in line with the estimate of the average U.K. gross markup (in manufacturing) by Haskel, Martin, and Small (1995, p. 30) of 2.0. Our high markup estimate appears more standard if it is regarded as the wedge between consumer prices and (principally) nominal wages, ${ }^{11}$ including the impact of cost

${ }^{11}$ Interest on the nominal wage bill also enters the cost expression, with implications we discuss shortly. elements we have not modeled explicitly. ${ }^{12}$ It should be remembered that the model is an abstraction of a model with imported intermediate goods and indirect taxes. With these unmodeled elements built into the empirical price-level series, the estimated markup of retail prices on nominal wages is increased. ${ }^{13}$

The estimated interest rate policy rule has responses to both the level and growth rate of inflation as well as to the deviation of output from the steady state. Because the interpretation

\footnotetext{
${ }^{12}$ By contrast, Haskel, Martin, and Small's (1995) markup estimate allows for costs of materials, so our markup estimate should be higher than theirs, other things equal.

${ }^{13}$ Therefore, our high estimate may be consistent with Britton, Larsen, and Small (2000) setting the U.K. steady-state markup value closer to 1.0 when calibrating a model with explicit imported intermediates.
} 


\section{Table 3}

\section{Parameters Fixed in Estimation}

\begin{tabular}{cc} 
Parameter & Value \\
\hline$\beta$ & $(1.04)^{-1 / 4}$ \\
$\alpha$ & 0.36 \\
$\delta$ & 0.025 \\
$\mu$ & 1.017 \\
$\psi_{l}$ & Such that $I=1$ \\
$\psi_{q}$ & Such that $q / m=0.25$ \\
$\lambda_{w}$ & 1.05
\end{tabular}

of the inflation responses is affected by the output response, we deal with the latter response first. As technology shocks are held constant, any output movements reflect the opening of the output gap and so also inflationary pressure. It is precisely this type of output variation that a monetary authority will have greatest interest in stabilizing. This may account for the output response being larger than is usual in estimated interest rate rules, which typically do not remove from the output measure the variation that is due to technology shocks.

The monetary policy reaction to inflation consists of a standard level response and a negative response to the change in inflation. We find that the inflation-change response, although not very precisely estimated, is negative and economically sizable. Under some parameter values, an estimated negative response to the change in inflation implies that policymakers have lagged inflation rather than current inflation in their rule. Our estimated $r_{\Delta \pi}$ response is, however, too large (in absolute value) for this to be the case. Instead, policymakers actually make different-signed shortrun responses to inflation, initially allowing a temporary reduction in the interest rate when inflation rises. To understand this response, one has to keep in mind the supply side of the CEE model. In the standard sticky-price model, the impulse responses of output and the output gap to a monetary policy shock are identical, because potential output depends on real shocks only. In the CEE model, however, this is not the case, because interest rates enter the production func-

\section{Table 4}

\section{Baseline Model Estimates, 1979:Q2-2005:Q4}

\begin{tabular}{|c|c|}
\hline \multicolumn{2}{|c|}{ Private sector parameters } \\
\hline$b$ & $\begin{array}{c}0.7739 \\
(0.0013)\end{array}$ \\
\hline$\lambda_{f}$ & $\begin{array}{c}2.2681 \\
(0.0323)\end{array}$ \\
\hline$\xi_{p}$ & $\begin{array}{c}0.9371 \\
(0.0004)\end{array}$ \\
\hline$\xi_{w}$ & $\begin{array}{c}0.0000 \\
(0.0083)\end{array}$ \\
\hline$\kappa$ & $\begin{array}{c}16.4333 \\
(0.1750)\end{array}$ \\
\hline$\sigma_{a}$ & $\begin{array}{c}\infty \\
(-)\end{array}$ \\
\hline \multicolumn{2}{|c|}{ Monetary policy rule parameters } \\
\hline$\rho$ & $\begin{array}{c}0.8720 \\
(0.0907)\end{array}$ \\
\hline$r_{\pi}$ & $\begin{array}{c}1.2813 \\
(0.4977)\end{array}$ \\
\hline$r_{y}$ & $\begin{array}{c}0.3517 \\
(0.6065)\end{array}$ \\
\hline$r_{\Delta \pi}$ & $\begin{array}{c}-0.5129 \\
(0.6971)\end{array}$ \\
\hline$r_{\Delta y}$ & $\begin{array}{c}0.4259 \\
(0.2759)\end{array}$ \\
\hline$\sigma_{R}$ & $\begin{array}{c}0.1564 \\
(0.0001)\end{array}$ \\
\hline
\end{tabular}

NOTE: The number of impulse-response steps used, which ideally should be determined statistically (see Hall et al., 2007), is 25 . A diagonal matrix is used to weight the responses.

tion, implying that potential output depends on the nominal interest rate (see Ravenna and Walsh, 2006, for further discussion). Holding constant its other effects, a cut in the interest rate stimulates potential output and helps inflation stabilization in the face of upward pressure on aggregate demand. Therefore, in the wake of a monetary policy shock, policymaker stabilization of the output gap and inflation takes a three-pronged approach: a large response to output to rein in incipient excessive aggregate demand $\left(r_{y}>0, r_{\Delta y}>0\right)$; a short-run cut in the interest rate as inflation rises to stimulate potential output $\left(r_{\Delta \pi}<0\right)$; and a sizable and durable 
Figure 2

\section{Estimated and Model Responses to a Monetary Policy Shock, 1962:Q3-2005:Q4}
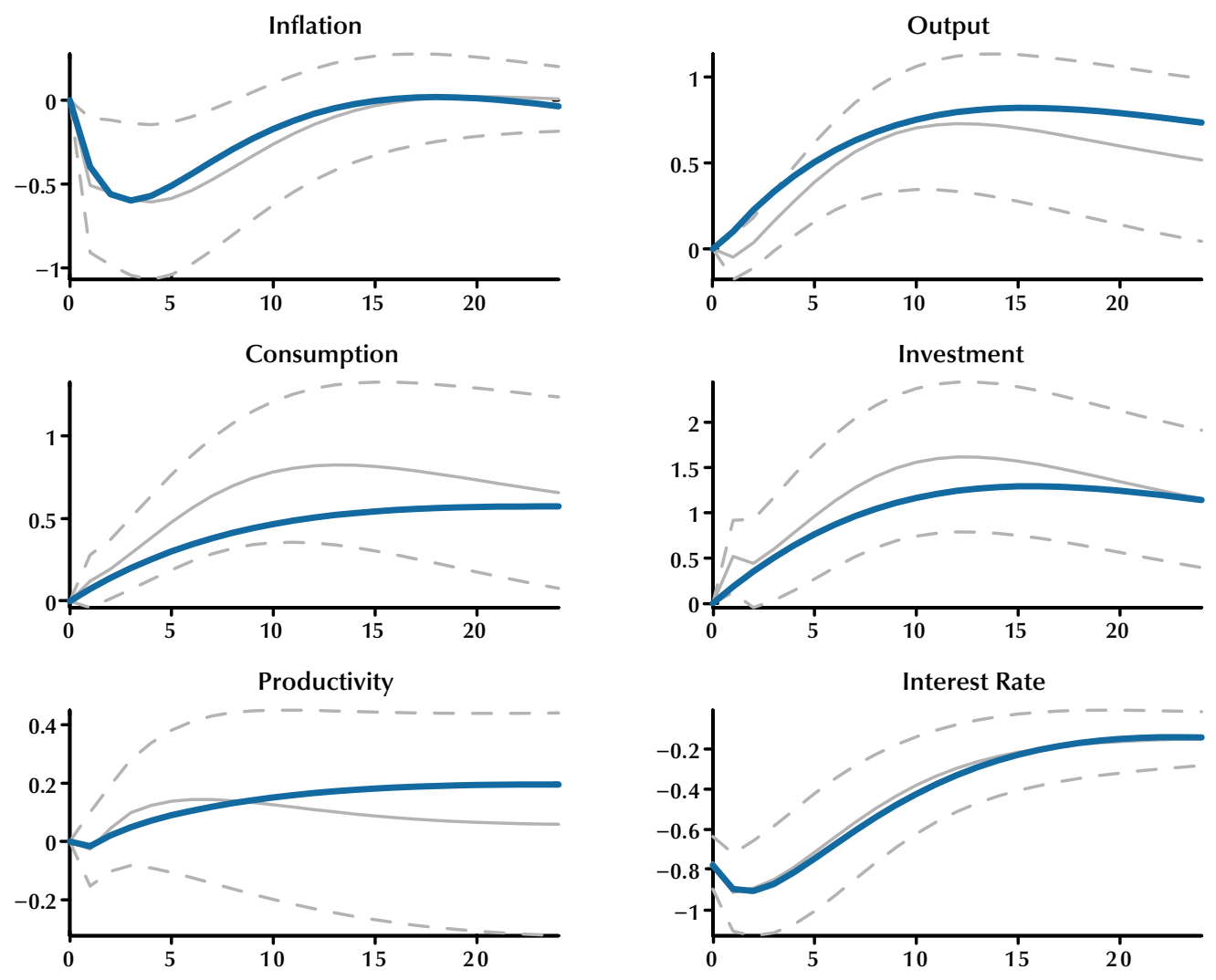

positive response of the interest rate to the level of inflation relative to the target $\left(r_{\pi}>1\right)$.

The estimates imply large investment adjustment costs, mainly driven by the matching of the smoother investment responses after the initial period; the model does not match the apparent initial spike in investment observed in the data.

Although the model allows for both wage stickiness and indexation of wages to price inflation, our parameter estimates imply that both these features are absent. ${ }^{14}$ On the other hand, price stickiness is substantial. Because full indexation of prices is superimposed on this price adjustment, it is not appropriate to infer from

\footnotetext{
${ }^{14}$ That is, equation (2) collapses to the usual static labor-supply condition, equating real wages to the marginal rate of substitution between consumption and leisure.
}

the low implied Calvo probability that prices are implausibly rigid; rather, the indexation implies substantial price movements every period, even with the underlying price stickiness. Empirical support for lagged inflation terms in the Phillips curve, when this parameter is estimated freely, is not universal (see, e.g., Ireland, 2001), so our assumption of full indexation may be restrictive. A lagged inflation term in the Phillips curve is, however, in line with the specification advocated by Blake and Westaway (1996) for U.K. monetary policy analysis.

The bottom line is that the estimates suggest that an emphasis on price stickiness as opposed to wage stickiness is appropriate in analyzing the United Kingdom. This emphasis is consistent with evidence for other European countries, such 


\section{Figure 3}

\section{Estimated and Model Responses to a Monetary Policy Shock, 1962:Q3-1979:Q1}
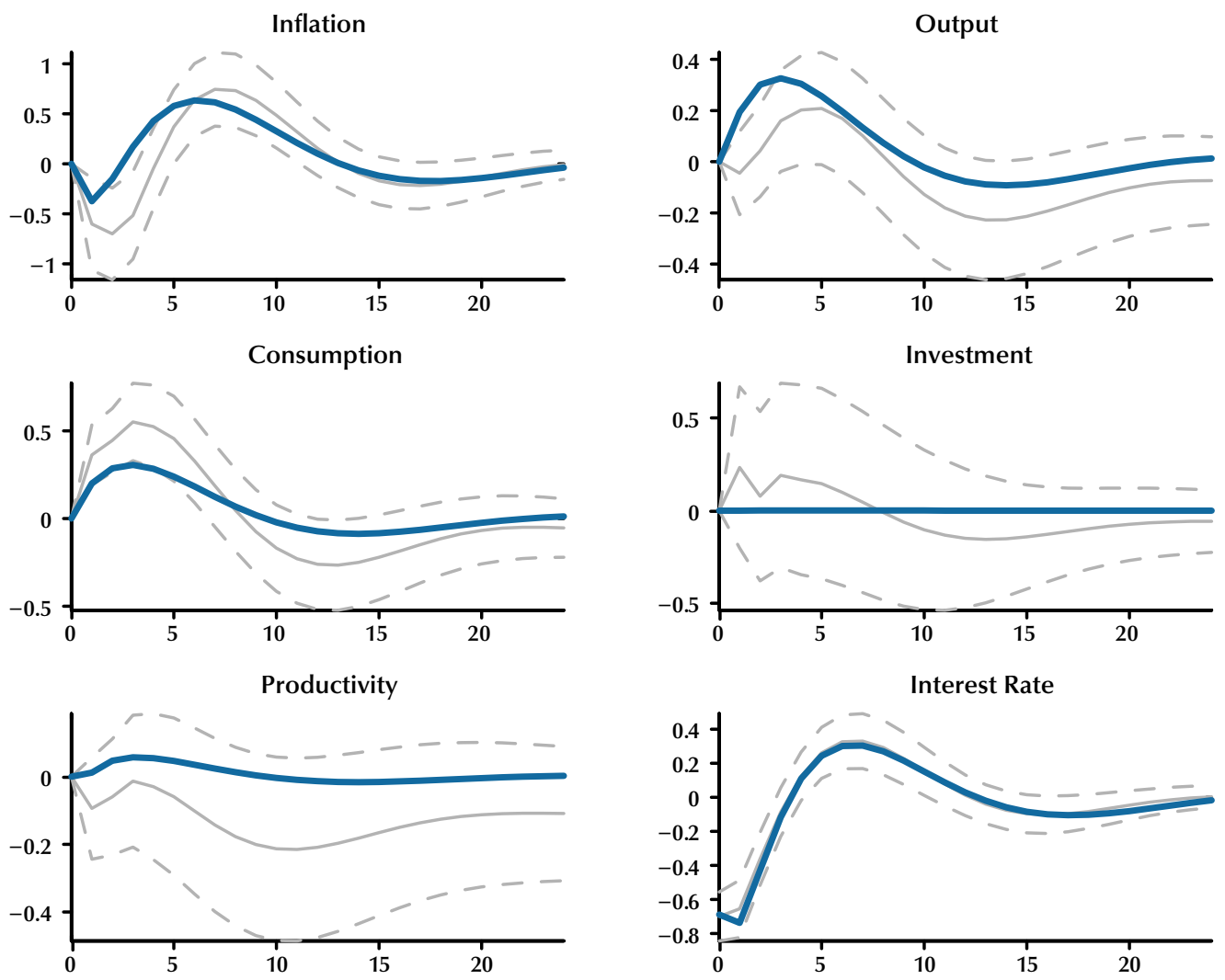

as Coenen, Levin, and Christoffel's (2007) study of nominal rigidities in Germany.

Factor utilization is not found to be important, the relevant parameter being driven to the boundary of its admissible region. Our VAR productivity responses are not very precisely estimated. Consequently, the model can explain output variation in terms of input responses and therefore has little need to rely on the intensive margin to explain the data responses.

\section{ESTIMATES INCLUDING PRE-1979 DATA}

In this section we present results for the long sample 1962-2005 as well as a sample using only pre-1979 data. The long-sample impulse responses and their matches are given in Figure 2, and those for the pre-1979 sample are given in Figure 3.

Parameter estimates for each sample are given in Table 5.

Turning to the policy rule first, the estimates deliver substantially lower inflation responses in the interest rate rule pre-1979, consistent with the assignment of inflation control to nonmonetary devices in the United Kingdom before 1979. But the response is large enough even in this sample period to deliver determinacy (i.e., a singlemodel equilibrium). ${ }^{15}$ The output response is "wrongly" (negatively) signed pre-1979. This may

${ }^{15}$ Our estimation routine considers only parameter combinations that deliver a single solution. An alternative procedure, which we have not pursued here, would be to consider both determinacy and indeterminacy regions and select a solution in the latter case using the minimal state-variable procedure. 
Table 5

Model Estimates for Samples that Include Pre-1970 Data

1962:Q3-2005:Q4

1962:Q3-1979:Q1

\begin{tabular}{lcc}
\hline Private sector parameters & & 0.5806 \\
$b$ & 0.9410 & $(0.0015)$ \\
& $(0.0003)$ & 1.2039 \\
$\lambda_{f}$ & 1.3904 & $(0.0035)$ \\
$\xi_{p}$ & $(0.0038)$ & 0.1703 \\
& 0.4478 & $(0.0025)$ \\
$\xi_{W}$ & $(0.0024)$ & 0.6069 \\
& 0.9897 & $(0.0008)$ \\
$\kappa$ & $(0.0003)$ & $\infty$ \\
& 49.9261 & $(-)$ \\
$\sigma_{a}$ & $(0.3288)$ & 0 \\
& 0.3900 & $(-)$ \\
Monetary policy rule parameters & $(0.0062)$ & \\
$\rho$ & & 0.7018 \\
& & $(0.0017)$ \\
$r_{\pi}$ & 0.9433 & 0.9642 \\
& $(0.0068)$ & $(0.0473)$ \\
$r_{y}$ & 1.2657 & -0.1980 \\
& $(0.1118)$ & $(0.0220)$ \\
$r_{\Delta \pi}$ & 0.0321 & 0.6066 \\
$r_{\Delta y}$ & $(0.0125)$ & $(0.0163)$ \\
$\sigma_{R}$ & 0.4128 & 0.1618 \\
& $(0.0034)$ & $(0.0182)$ \\
& 0.0879 & 0.1719 \\
& $(0.0104)$ & $(0.0002)$ \\
& 0.1959 & $(0.0002)$ \\
\end{tabular}

be another reflection of the lack of monetary policy response to inflationary pressure because, as noted earlier, the output coefficient captures responses to the specific type of output increases that are likely to raise inflation. An additional departure from our baseline estimates is that both sets of estimates that include pre-1979 data have a more standard (i.e., positive) interest rate response to the change in inflation.

A major feature of the structural parameters when we move away from our baseline sample is that there is now sizable nominal wage rigidity. Another difference from our baseline structural parameter estimates pertains to investment behavior. In the pre-1979 sample, the model cannot match the empirical investment impulse response; the best the model can do is to suppress investment altogether (and so generate a flat investment model response in Figure 3). Accordingly, the investment adjustment-cost parameter estimate becomes arbitrarily large.

It is tempting to suggest that our anomalous results for investment occur because the estimates including pre-1979 data are distorted by the existence of unmodeled breaks in monetary policy regime. But this does not really provide a satisfactory answer why we get these particular results. It is not obvious that estimated impulse responses over a sample that includes multiple regimes will be perverse in their shape; they are, more or less, 
an average of the responses observed across each regime, we should expect them to be of standard shape. Instead of this, we get model estimates that appear to extinguish the investment portion of aggregate demand.

It is likely instead that U.K. government policy is indeed the culprit for the anomalies in the pre1979 results, but the policy actions responsible were microeconomic interventions in the economy and not monetary policy. Before the 1980s, many large industries (e.g., steel and telecommunications) were principally government-owned. What is more, in a misguided effort to control inflation by nonmonetary means, governments frequently intervened in the pricing decisions of their enterprises. For example, George Brown, then Secretary of State for Economic Affairs, in 1965 said that the government was operating a price-control policy "in the field of government responsibility so far as charges for which they are responsible, prices which are their responsibility..."(Glasgow Herald, 1965). Ted Heath, prime minister 1970-74, said shortly before being elected that "we are going to see to it that the State does not put up its prices and charges with gay abandon” (Russell, 1970). The attempt to enforce this policy led to considerable interference in government enterprises' operations, so much so that Anthony Crosland, a leading Labour Party figure, cited 1970-71 as a period that displayed a poor "balance...between Ministerial control and entrepreneurial freedom" (Crosland, 1974, p. 39).

From around 1978, however, it became much more standard for government-owned enterprises to base their pricing and investment decisions on market signals, with a government report on the subject in 1978 stating that the "Government intends that the nationalized industries will not be forced into deficits by restraints on their prices"(House of Commons, 1979). The stepping away by government from management of investment decisions was cemented by the privatization of many government enterprises in the 1980s.

Because the pre-1978 government interventions blocked investment from responding to market signals, including those from monetary policy shocks, one can understand why investment responses might deviate greatly from those predicted by our model, in which investment behavior is based on optimal firm choices. Government prohibitions on a firm's ability to raise prices might cut off funds to the firm, thus distorting investment decisions. On the other hand, for given monetary policy, government intervention in investment decisions might merely transfer aggregate demand pressure from investment to other categories of spending, rather than affect total demand. So impulse responses other than those for investment might still be compatible with the model, which is essentially what we find.

\section{EXTENSIONS}

In this section, we report further results regarding the robustness of our results to alternative data definitions (under "Alternative Investment Series") and our choice of regime dates (under "VAR Stability and Regime Breaks").

\section{Alternative Investment Series}

The BEQM model and such sources as the Bank of England Inflation Report use a slightly narrower definition of investment than we use in our analysis. This narrower definition is known as "business investment" (though, like our series, it includes investment by government enterprises).

We use this alternative investment series and examine the effect on our results. In Figure 4, we show that using this series in our VAR makes little difference in the empirical responses to a monetary policy shock. ${ }^{16}$ The parameter estimates using this series are given in Table 6. These are little changed from the baseline parameter estimates, with some important exceptions. Most notably, the policy rule estimates are much less precisely estimated and feature a much lower

\footnotetext{
16 The sample period we now use, 1980:Q1-2005:Q4, is slightly shorter than the 1979:Q2-2005:Q4 sample we used for our baseline results, owing to difficulty obtaining parameter estimates for 1979-2005 with the business investment series.
} 


\section{Figure 4}

\section{Estimated and Model Responses to a Monetary Policy Shock, with Alternative Investment Series, 1980:Q1-2005:Q4}
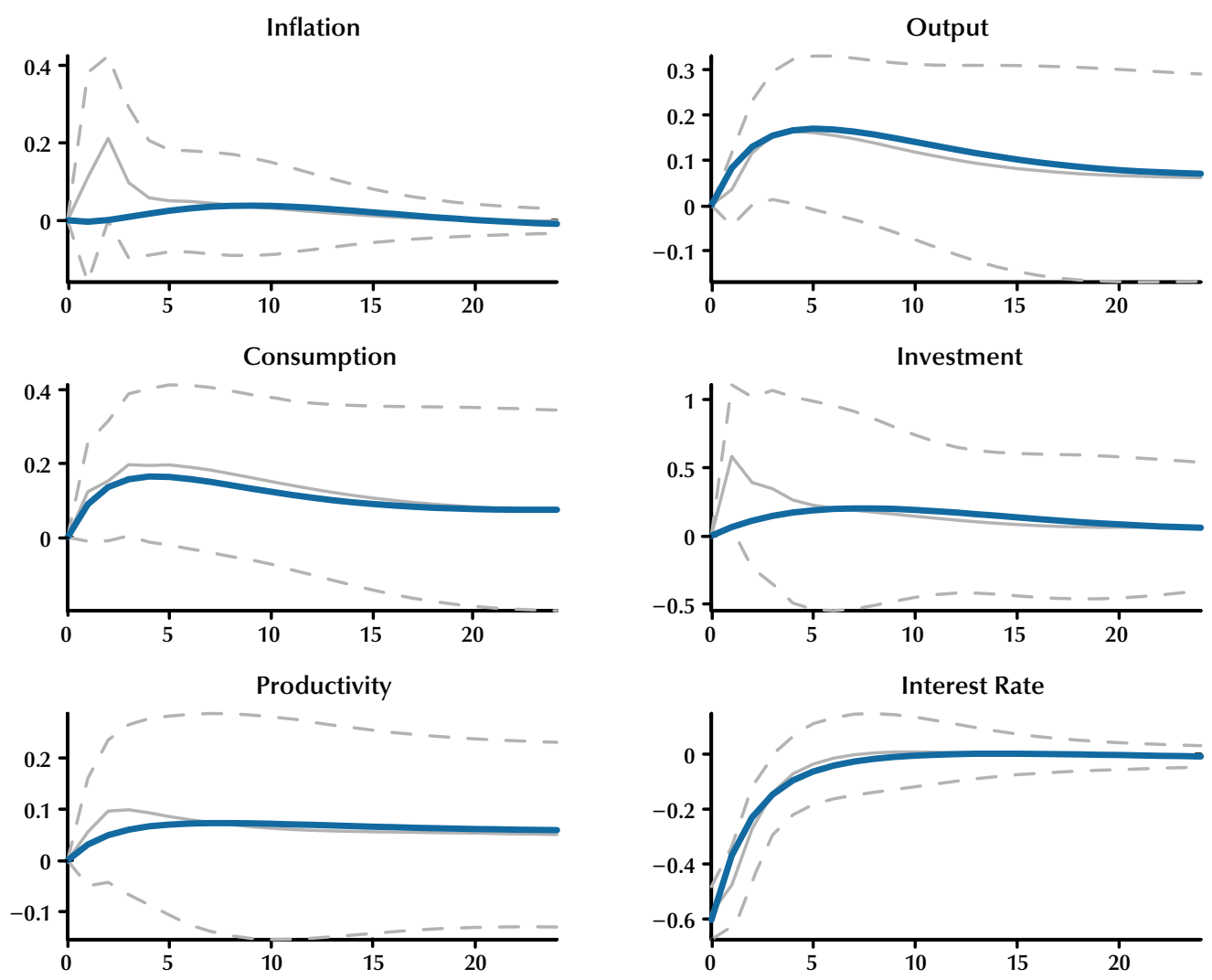

estimated response to output; and the alternative estimates give roughly equal importance to price and wage stickiness, whereas in the baseline estimates prices were much stickier than wages.

\section{VAR Stability and Regime Breaks}

As noted above, our data cover the whole 1962-2005 period, but our baseline structural estimates are based on a sample covering only the period since the late 1970s, reflecting the changes in U.K. industrial and monetary policies that took place around that time. To investigate further the issue of regime break dates, in Table 7 we follow Boivin and Giannoni (2002, p. 99) by investigating the stability of the VAR when it is estimated for the long sample 1962:Q1-2005:Q4.
We report the $p$-values for the constancy of the coefficients associated with each group of regressors in the VAR. The break dates suggested by the test are also reported, and those highlighted in bold achieve statistical significance at the 10 percent level or better.

The results for the baseline VAR specification-that is, the VAR specification underlying the Figure 2 impulse responses-occupy the top half of the table. The results suggest a significant break in the inflation equation around 1975:Q2. This date, however, does not constitute a monetary policy regime break; instead, the mid-1975 instability reflects a one-time shock to industrial policy. The previously described U.K. government policy of holding down nationalized industries' 
prices underwent an adjustment in this period, with prices allowed to rise to eliminate the accumulated discrepancy with costs. The large effect on consumer prices that resulted has sometimes been categorized as tantamount to a substantial increase in indirect taxes (Wilson, 1984, p. 50). The test statistics mechanically take this large shock as evidence of regime change, though, economically, it does not amount to the sort of change in systematic policy responses that truly qualify as a policy regime shift. The remaining stability rejections are spread over 1977-81 and so are roughly in line with our assumption of a 1979 break date.

Recall that our VAR does not use detrended real data, nor does it include a trend as a regressor. Some work on U.S. data-e.g., Rotemberg and Woodford (1997), Boivin and Giannoni (2002), and Giannoni and Woodford (2005)—detrends real variables before putting them in the VAR. We report in the bottom half of Table 7 the stability results for our VAR when our specification is modified by replacing the four real variables with their detrended counterparts. The detrending assumes that the log real variables are driven by a broken linear trend, with constant and trend breaks in both 1973:Q4 and 1981:Q4.

Besides continuing to show a break in 1975 in some of the inflation coefficients, these stability results largely reaffirm a focus on a regime break around the early 1980s (specifically, 1980 or 1981). Two of the significant rejections of stability do suggest a break in 1984 in GDP and productivity behavior, but these rejections can be discounted as reflecting the temporary disturbances to output from the coal-mining strike of that year.

One puzzling aspect of the results with detrended variables is that the interest rate equation no longer registers any significant regime break. This, however, is not decisive evidence against the importance of monetary policy regime change. For one thing, relatively minor and statistically insignificant changes in the VAR coefficients can imply large changes in the implied "long-run response" of the interest rate to endogenous variables. This is the case here because, despite the lack of rejection of stability, the VAR

\section{Table 6}

\section{Estimates Using Alternative Investment Series, 1980:Q1-2005:Q4}

\begin{tabular}{|c|c|}
\hline \multicolumn{2}{|c|}{ Private sector parameters } \\
\hline$b$ & $\begin{array}{c}0.6621 \\
(0.0015)\end{array}$ \\
\hline$\lambda_{f}$ & $\begin{array}{c}2.4922 \\
(0.0198)\end{array}$ \\
\hline$\xi_{p}$ & $\begin{array}{c}0.8465 \\
(0.0020)\end{array}$ \\
\hline$\xi_{w}$ & $\begin{array}{c}0.9409 \\
(0.0008)\end{array}$ \\
\hline$\kappa$ & $\begin{array}{c}14.2684 \\
(0.2340)\end{array}$ \\
\hline$\sigma_{a}$ & $\begin{array}{c}\infty \\
(-)\end{array}$ \\
\hline \multicolumn{2}{|c|}{ Monetary policy rule parameters } \\
\hline$\rho$ & $\begin{array}{c}0.8426 \\
(1.2144)\end{array}$ \\
\hline$r_{\pi}$ & $\begin{array}{c}2.0747 \\
(21.0751)\end{array}$ \\
\hline$r_{y}$ & $\begin{array}{c}0.0546 \\
(1.0372)\end{array}$ \\
\hline$r_{\Delta \pi}$ & $\begin{array}{c}-0.2935 \\
(0.0368)\end{array}$ \\
\hline$r_{\Delta y}$ & $\begin{array}{c}0.4140 \\
(2.1327)\end{array}$ \\
\hline$\sigma_{R}$ & $\begin{array}{c}0.1509 \\
(0.0001)\end{array}$ \\
\hline
\end{tabular}

equation for the interest rate underlying the final row of the table has a long-run solution with an interest rate response to (annualized) inflation of about 0.3 ; but this response rises to 1.0 on restricting the sample to $1979-2005 .{ }^{17}$ Furthermore, the inflation VAR equation now exhibits a significant early-1980s break, which is indirect support for a monetary policy regime change around that time.

\footnotetext{
${ }^{17}$ In some contexts (see, e.g., Rotemberg and Woodford, 1997, and Rudebusch, 1998) the VAR equation for the interest rate coincides with the interest rate policy rule. This is not the case in our analysis, as the policy rule that we use in estimation differs from the VAR equation. But solving the reduced-form VAR interest rate equation for its long-run solution nevertheless provides a means of crosschecking the stability test results.
} 
Table 7

VAR Stability Tests, 1962:Q3-2005:Q4

\begin{tabular}{|c|c|c|c|c|c|c|}
\hline \multirow[b]{2}{*}{ Dependent variable } & \multicolumn{6}{|c|}{ Regressor } \\
\hline & $\pi$ & y & c & $i$ & $y-h$ & $r$ \\
\hline \multicolumn{7}{|c|}{ 1. Baseline VAR specification } \\
\hline$\pi$ & $\begin{array}{c}0.002 \\
1975: Q 2\end{array}$ & $\begin{array}{c}0.001 \\
1977: Q 1\end{array}$ & $\begin{array}{c}0.713 \\
1975: Q 3\end{array}$ & $\begin{array}{c}0.153 \\
1971: Q 1\end{array}$ & $\begin{array}{c}0.510 \\
1970: Q 4\end{array}$ & $\begin{array}{c}0.574 \\
1973: Q 2\end{array}$ \\
\hline$y$ & $\begin{array}{c}0.127 \\
1972: Q 3\end{array}$ & $\begin{array}{c}0.682 \\
1975: Q 3\end{array}$ & $\begin{array}{c}0.373 \\
1990: Q 2\end{array}$ & $\begin{array}{c}0.358 \\
1976: Q 1\end{array}$ & $\begin{array}{c}0.948 \\
1975: Q 3\end{array}$ & $\begin{array}{c}0.347 \\
1977: Q 4\end{array}$ \\
\hline c & $\begin{array}{c}0.469 \\
1990: Q 2\end{array}$ & $\begin{array}{c}0.444 \\
1990: Q 2\end{array}$ & $\begin{array}{c}0.001 \\
1977: Q 1\end{array}$ & $\begin{array}{c}0.012 \\
\text { 1980:Q2 }\end{array}$ & $\begin{array}{c}0.001 \\
1977: Q 1\end{array}$ & $\begin{array}{c}0.008 \\
\text { 1980:Q2 }\end{array}$ \\
\hline$i$ & $\begin{array}{c}0.553 \\
1973: Q 1\end{array}$ & $\begin{array}{c}0.844 \\
1968: Q 4\end{array}$ & $\begin{array}{c}0.788 \\
1976: Q 1\end{array}$ & $\begin{array}{c}0.195 \\
\text { 1979:Q2 }\end{array}$ & $\begin{array}{c}0.524 \\
1975: Q 3\end{array}$ & $\begin{array}{c}0.711 \\
1975: Q 3\end{array}$ \\
\hline$y-h$ & $\begin{array}{c}0.382 \\
1973: Q 2\end{array}$ & $\begin{array}{c}0.943 \\
1975: Q 3\end{array}$ & $\begin{array}{c}0.922 \\
1973: Q 2\end{array}$ & $\begin{array}{c}0.869 \\
1973: Q 2\end{array}$ & $\begin{array}{c}0.361 \\
1990: Q 2\end{array}$ & $\begin{array}{c}0.199 \\
1974: Q 1\end{array}$ \\
\hline$r$ & $\begin{array}{c}0.275 \\
1977: Q 4\end{array}$ & $\begin{array}{c}0.000 \\
1981: Q 2\end{array}$ & $\begin{array}{c}0.000 \\
1981: Q 2\end{array}$ & $\begin{array}{c}0.006 \\
1977: Q 4\end{array}$ & $\begin{array}{c}0.000 \\
1981: Q 2\end{array}$ & $\begin{array}{c}0.471 \\
1973: Q 1\end{array}$ \\
\hline \multicolumn{7}{|c|}{ 2. Baseline VAR specification with $y, c, i, y-h$ detrended } \\
\hline$\pi$ & $\begin{array}{c}0.002 \\
1975: Q 2\end{array}$ & $\begin{array}{c}0.072 \\
1975: Q 2\end{array}$ & $\begin{array}{c}0.040 \\
1981: Q 4\end{array}$ & $\begin{array}{c}0.004 \\
1976: Q 1\end{array}$ & $\begin{array}{c}0.567 \\
1978: Q 4\end{array}$ & $\begin{array}{c}0.741 \\
1988: Q 4\end{array}$ \\
\hline$y$ & $\begin{array}{c}0.110 \\
1972: Q 3\end{array}$ & $\begin{array}{c}0.036 \\
1984: Q 1\end{array}$ & $\begin{array}{c}0.121 \\
\text { 1981:Q2 }\end{array}$ & $\begin{array}{c}0.224 \\
1987: Q 2\end{array}$ & $\begin{array}{c}0.296 \\
1981: Q 4\end{array}$ & $\begin{array}{c}0.867 \\
1977: Q 4\end{array}$ \\
\hline c & $\begin{array}{c}0.738 \\
1970: Q 1\end{array}$ & $\begin{array}{c}0.063 \\
\text { 1981:Q3 }\end{array}$ & $\begin{array}{c}0.065 \\
\text { 1980:Q2 }\end{array}$ & $\begin{array}{c}0.095 \\
\text { 1980:Q2 }\end{array}$ & $\begin{array}{c}0.105 \\
1975: Q 2\end{array}$ & $\begin{array}{c}0.001 \\
\text { 1980:Q2 }\end{array}$ \\
\hline$i$ & $\begin{array}{c}0.812 \\
1968: Q 4\end{array}$ & $\begin{array}{c}0.269 \\
1987: Q 1\end{array}$ & $\begin{array}{c}0.239 \\
1985: Q 1\end{array}$ & $\begin{array}{c}0.014 \\
1976: Q 4\end{array}$ & $\begin{array}{c}0.049 \\
\text { 1980:Q1 }\end{array}$ & $\begin{array}{c}0.662 \\
1990: Q 2\end{array}$ \\
\hline$y-h$ & $\begin{array}{c}0.325 \\
1972: Q 3\end{array}$ & $\begin{array}{c}0.147 \\
1984: Q 1\end{array}$ & $\begin{array}{c}0.078 \\
1984: Q 1\end{array}$ & $\begin{array}{c}0.187 \\
1976: Q 4\end{array}$ & $\begin{array}{c}0.476 \\
1981: Q 4\end{array}$ & $\begin{array}{c}0.665 \\
1970: Q 1\end{array}$ \\
\hline$r$ & $\begin{array}{c}0.425 \\
1977: Q 4\end{array}$ & $\begin{array}{c}0.813 \\
1980: Q 1\end{array}$ & $\begin{array}{c}0.714 \\
1986: Q 1\end{array}$ & $\begin{array}{c}0.801 \\
\text { 1990:Q3 }\end{array}$ & $\begin{array}{c}0.865 \\
\text { 1998:Q3 }\end{array}$ & $\begin{array}{c}0.460 \\
1976: Q 3\end{array}$ \\
\hline
\end{tabular}

NOTE: Values reported are the $p$-values for the Andrews (1993) sup-Wald test, computed using the procedure of Diebold and Chen (1996). The null hypothesis assumes no structural breaks, whereas the alternative hypothesis has breaks in the constant and group of lag coefficients on the indicated regressor. Each panel also gives the break-date associated with the $p$-value.

\section{CONCLUSIONS}

In this paper, we have estimated the Christiano, Eichenbaum, and Evans (2005) model on U.K. data. Although CEE found plausible estimates on U.S. data when treating the period since the 1960 s as a single regime, for the United Kingdom it appears that more satisfactory estimates emerge if pre-1979 data are excluded; otherwise, the estimates imply degenerate behavior of investment. This result is consistent with policy regime changes being an important factor in the postwar U.K. economy. These regime changes include not only changes in the role assigned to monetary policy but also shifts toward making investment decisions more closely related to market forces. Another important implication of our estimates is that price stickiness, rather than wage stickiness, is the major source of nominal rigidity in the United Kingdom. 


\section{REFERENCES}

Altig, David; Christiano, Lawrence J.; Eichenbaum, Martin and Linde, Jesper. "Firm-Specific Capital, Nominal Rigidities and the Business Cycle.” NBER Working Paper No. 11034, National Bureau of Economic Research, 2005.

Andrews, Donald W.K. "Tests for Parameter Instability and Structural Change with Unknown Change Point." Econometrica, July 1993, 61(4), pp. 821-56.

Aoki, Kosuke; Proudman, James and Vlieghe, Gertjan. "House Prices, Consumption and Monetary Policy: A Financial Accelerator Approach.” Working Paper No. 169, Bank of England, 2002.

Benati, Luca. "Evolving Post-World War II U.K. Economic Performance." Journal of Money, Credit, and Banking, August 2004, 36(4), pp. 691-717.

Blake, Andrew P. and Westaway, Peter F. "Credibility and the Effectiveness of Inflation Targeting Regimes." Manchester School of Economic and Social Studies, June 1996, 64(Suppl 1), pp. 28-50.

Boivin, Jean and Giannoni, Marc P. “Assessing Changes in the Monetary Transmission Mechanism: A VAR Approach." Federal Reserve Bank of New York Economic Policy Review, May 2002, 8(1), pp. 97-111.

Britton, Erik; Larsen, Jens D.J. and Small, Ian. "Imperfect Competition and the Dynamics of Mark-ups.” Working Paper No. 110, Bank of England, 2000.

Calvo, Guillermo A. "Staggered Prices in a UtilityMaximizing Framework." Journal of Monetary Economics, September 1983, 12(3), pp. 383-98.

Castelnuovo, Efrem and Surico, Paolo. "The Price Puzzle: Fact or Artefact?” Working Paper No. 288, Bank of England, 2006.

Christiano, Lawrence J.; Eichenbaum, Martin and Evans, Charles L. "Monetary Policy Shocks: What Have We Learned and to What End?" in J.B. Taylor and M. Woodford, eds., Handbook of Macroeconomics. Volume 1A. Amsterdam: Elsevier/North Holland, 1999, pp. 65-148.
Christiano, Lawrence J.; Eichenbaum, Martin and Evans, Charles L. "Nominal Rigidities and the Dynamic Effects of a Shock to Monetary Policy." Journal of Political Economy, February 2005, 113(1), pp. 1-45.

Coenen, Günter; Levin, Andrew T. and Christoffel, Kai. "Identifying the Influences of Nominal and Real Rigidities in Aggregate Price-Setting Behavior." Journal of Monetary Economics, 2007 (forthcoming).

Crosland, Anthony. Socialism Now and Other Essays. London: Jonathan Cape, 1974.

Del Negro, Marco; Schorfheide, Frank; Smets, Frank and Wouters, Rafael. "On the Fit and Forecasting Performance of New-Keynesian Models.” ECB Working Paper No. 491, European Central Bank, 2005.

DiCecio, Riccardo. "Comovement: It’s Not a Puzzle." Working Paper 2005-035B, Federal Reserve Bank of St. Louis, 2005.

Diebold, Francis X. and Chen, Celia. "Testing Structural Stability with Endogenous Breakpoint: A Size Comparison of Analytic and Bootstrap Procedures." Journal of Econometrics, June 1996, 70(1), pp. 221-41.

Erceg, Christopher J.; Henderson, Dale W. and Levin, Andrew T. "Optimal Monetary Policy with Staggered Wage and Price Contracts." Journal of Monetary Economics, October 2000, 46(2), pp. 281-313.

Fuhrer, Jeffrey C. "Habit Formation in Consumption and Its Implications for Monetary Policy Models.” American Economic Review, June 2000, 90(3), pp. 367-90.

Giannoni, Marc P. and Woodford, Michael. "Optimal Inflation Targeting Rules," in B. Bernanke and M. Woodford, eds., The Inflation-Targeting Debate. Chicago: University of Chicago Press, 2005, pp. 93-162.

Glasgow Herald. "Brown’s Pay Policy Approved." October 1, 1965, p. 5. 


\section{DiCecio and Nelson}

Goodhart, Charles A.E. "The Conduct of Monetary Policy.” Economic Journal, June 1989, 99(396), pp. 293-346.

Hall, Alastair; Inoue, Atsushi; Nason, James M. and Rossi, Barbara. "Information Criteria for Impulse Response Function Matching Estimation of DSGE Models." Working Paper 2007-10, Federal Reserve Bank of Atlanta, May 2007.

Harrison, Richard; Nikolov, Kalin; Quinn, Meghan; Ramsay, Gareth; Scott, Alasdair and Thomas, Ryland. The Bank of England Quarterly Model. London: Bank of England, 2005.

Haskel, Jonathan; Martin, Christopher and Small, Ian. "Price, Marginal Cost and the Business Cycle." Oxford Bulletin of Economics and Statistics, February 1995, 57(1), pp. 25-41.

House of Commons, Parliament of the United Kingdom. House of Commons Debates, December 5, 1979, p. 563 (quoting U.K. Government, White Papers on Nationalized Industries, London: HMSO, 1978).

Ireland, Peter N. "Sticky-Price Models of the Business Cycle: Specification and Stability." Journal of Monetary Economics, February 2001, 47(1), pp. 3-18.

King, Mervyn A. Public Policy and the Corporation. London: Chapman and Hall, 1977.

Levin, Andrew T.; Onatski, Alexei; Williams, John C. and Williams, Noah. "Monetary Policy under Uncertainty in Micro-Founded Macroeconometric Models.” NBER Macroeconomics Annual, 2005, 20(1), pp. 229-87.

Neiss, Katharine S. and Nelson, Edward. "The RealInterest-Rate Gap as an Inflation Indicator." Macroeconomic Dynamics, April 2003, 7(2), pp. 239-62.

Nelson, Edward and Nikolov, Kalin. "Monetary Policy and Stagflation in the U.K." Journal of Money, Credit, and Banking, June 2004, 36(3), pp. 293-318.

Newey, Whitney K. and McFadden, Daniel. "Large
Sample Estimation and Hypothesis Testing," in Robert Engle and Dan McFadden, eds., Handbook of Econometrics. Volume 4. Amsterdam:

Elsevier/North Holland, 1994, pp. 2111-45.

Obstfeld, Maurice. "Exchange Rates and Adjustment: Perspectives from the New Open-Economy Macroeconomics." Bank of Japan Monetary and Economic Studies, December 2002, 20(4), pp. 23-46.

Pagan, Adrian. "Addendum to Report on Modelling and Forecasting at the Bank of England." Bank of England Quarterly Bulletin, Summer 2005, 45(2), pp. 190-93.

Ravenna, Federico and Walsh, Carl E. "Optimal Monetary Policy with the Cost Channel." Journal of Monetary Economics, May 2006, 53(2), pp. 199-216.

Ravn, Morten O. "Permanent and Transitory Shocks and the U.K. Business Cycle." Journal of Applied Econometrics, January/February 1997, 12(1), pp. 27-48.

Rotemberg, Julio J. and Woodford, Michael. "An Optimization-Based Econometric Framework for the Evaluation of Monetary Policy.” NBER Macroeconomics Annual, 1997, 12(1), pp. 297-346.

Rudebusch, Glenn D. "Do Measures of Monetary Policy Shocks in a VAR Make Sense?” International Economic Review, November 1998, 39(4), pp. 907-31.

Russell, William. “'Pushover’ Jenkins Surrendered to Unions, Says Heath.” Glasgow Herald, June 3, 1970, p. 8.

Sims, Christopher A. and Zha, Tao. "Were There Regime Switches in U.S. Monetary Policy?" American Economic Review, May 2006, 96(1), pp. 54-81.

Smets, Frank and Wouters, Raf. "An Estimated Stochastic Dynamic General Equilibrium Model of the Euro Area." Journal of the European Economic Association, 2003, 1(5), pp. 1123-75.

Wilson, Thomas. "Monetarism in Britain," in T. Wilson, ed., Inflation, Unemployment, and the Market. Oxford: Clarendon Press, 1984, pp. 41-78. 


\section{APPENDIX}

\section{Data Sources and Definitions}

Nominal interest rate: U.K. Treasury bill rate, quarterly average. Source: Haver-IFS, quarterly average series.

Output: real GDP, seasonally adjusted, quarterly, series abmi.q.

Source: U.K. Office of National Statistics (ons.gov.uk), downloaded May 2006.

Private household consumption: seasonally adjusted, quarterly, series abjr.q.

Source: ons.gov.uk, downloaded May 2006.

Investment: gross fixed capital formation, seasonally adjusted, quarterly, series npqt.q.

Source: ons.gov.uk, downloaded May 2006.

Alternative investment series: business investment at 2003 prices, seasonally adjusted, quarterly, series npel.q.

Source: ons.gov.uk, downloaded August 2006.

Productivity: $Y / H$, where $H=$ hours worked.

Source for H: series ybus.q (source: U.K. Office of National Statistics [ONS]), with splice into Ravn (1997) U.K. hours worked series to obtain pre-1971:Q1 data.

Inflation: $\log$ difference of $P$, where $P$ is a seasonally adjusted consumer price series. $P$ was constructed as follows: A quarterly average of the retail price index (RPI) was spliced into a quarterly average of RPIX (RPI excluding mortgage interest payment) after 1973, the series was seasonally adjusted, then tax-related spikes of 4 percent (in 1979:Q3) and 2 percent (1990:Q2) were removed from the series. The seasonal regressions underlying the seasonal adjustment used the log-change as the dependent variable, and seasonal patterns were allowed to differ across 1955-76, 1976-86, and 1987-2005.

Source for the monthly RPI underlying the quarterly averages: ONS (ons.gov.uk). The ONS, however, provides RPIX data only from January 1987. An unofficial RPIX series starting in 1974 has, however, been constructed at the Bank of England, and this series underlies studies such as Nelson and Nikolov (2004) and Benati (2004). The OECD-Haver service also provides an RPIX series (though beginning only in 1975) that closely matches this series. We used the quarterly average of the unofficial RPIX series for 1974-87 and spliced it into the quarterly average of the official RPIX series that begins in 1987. Splicing this RPIX series at 1974:Q1 with RPI delivered the RPI/RPIX quarterly average series underpinning $P$. 
